\title{
Decomposition of Spartina anglica roots and rhizomes in a salt marsh of the Westerschelde Estuary*
}

\author{
M. A. Hemminga ${ }^{1}$, C. J. Kok ${ }^{2}$, W. de Munck ${ }^{1}$ \\ ${ }^{1}$ Delta Institute for Hydrobiological Research, Yerseke, The Netherlands \\ ${ }^{2}$ Laboratory of Aquatic Ecology, Catholic University of Nijmegen, The Netherlands
}

\begin{abstract}
Decomposition of roots of the salt marsh grass Spartina anglica was investigated using litter bags. The pattern of disappearance of the root material was essentially the same at soil depths of 30,15 , and $3 \mathrm{~cm}$, and above-ground. Average calculated turnover time for $S$. anglica root material varied between 2.0 and $3.9 \mathrm{yr}$. These differences are due to variations in decay rates at the various depth levels and marsh locations. At the creek levee and low marsh study site, decomposition rate decreased with depth. This phenomenon was less obvious at the moderately vegetated middle marsh site. A possible explanation of these observations may be found in the interactions of living roots with the decomposer community in the salt marsh sediment. $S$. anglica roots decomposed faster with increasing elevation of the marsh location, indicating that inundation frequency is an important factor in determining the rate of decay processes. Percentage nitrogen in the litter increased in time, both below-ground and above-ground. There was a strong positive correlation between the percentage nitrogen and the percentage weight loss of root material. In contrast to nitrogen levels, the percentage of extractable protein in the root litter decreased rapidly to undetectable levels a few months after the start of the experiment. This finding underlines the difficulty in interpreting elemental $N$ values in terms of resource quality. The course of protein decrease was similar on all depth levels and locations; this suggests that the transformation of compounds valuable to microbial metabolism, such as proteins, is much less responsive to environmental factors than the majority of plant materials.
\end{abstract}

\section{INTRODUCTION}

Based mainly on studies of the above-ground part of the vegetation, temperate salt marshes have long been known as very productive plant communities. More recent data on below-ground production only have strengthened this fundamental idea. It has become evident that salt marsh plant species annually produce roots and rhizomes in amounts which at least equal the above-ground production, but often are considerably greater (Good et al. 1982, Howarth \& Hobbie 1982, Long \& Mason 1983). Additional to this structural component, there probably is excretion of organic molecules by roots and rhizomes (e.g. Russel 1977) which is generally not accounted for in biomass production studies.

Notwithstanding this high annual production, accumulation of organic matter normally does not

\footnotetext{
- Delta Institute communication No. 406
}

occur in soils of European tidal salt marshes, with the exception of marshes under Eu-Atlantic climatic conditions (Beeftink 1976, Beeftink et al. 1977). This predominantly mineral character of European salt marsh soils may indicate that mineralization in situ - possibly in combination with seepage of compounds produced by subterranean decomposition processes - predominates over production.

Evaluations of anaerobic sulfate reduction, which has been shown to be of particular importance in decomposition of organic matter at least in North-American salt marsh soils, have indicated that by export of reduced inorganic sulphur compounds from the soil to nearby creeks and estuaries, a significant part of the below-ground production may become available to coastal ecosystems (Howarth \& Teal 1980, Howarth et al. 1983). The potential importance of salt marsh belowground primary production as fuel for adjacent aquatic food chains obviously is mediated by decomposition processes. However, in contrast to the degradation of 
above-ground litter, very little is known of the decomposition of roots and rhizomes in the salt marsh soil.

This study investigates the below-ground pattern of disappearance of Spartina anglica root material at different depth levels. A comparison was made with above-ground decay. Furthermore, the effect of marsh location was evaluated. To assess qualitative changes in the composition of the litter during the decomposition process, levels of nitrogen and extractable protein of the litter were determined. The study was carried out in an estuarine salt marsh in the S. W. Netherlands, and is one of a series on production and decomposition in these marshes (Wolff et al. 1979, Buth \& de Wolf 1985 , Groenendijk 1984, Buth 1987, Groenendijk \& VinkLievaart 1987).

\section{MATERIALS AND METHODS}

The study was carried out on a salt marsh called 'Zuidgors', on the northern side of the Westerschelde estuary (Fig. 1) in the S. W. Netherlands. The mean salinity at high tide in this part of the estuary is approximately $12.5 \% \mathrm{Cl}^{-}$. Three locations on the marsh were chosen representing lower marsh (LM), middle marsh (MM) and creek levees (CL). The percentage vegetation cover on the sites during the growing season were: LM: $85 \%$, MM: $40 \%$, CL: $100 \%$. Elevations of these sites were $2.07,2.28$, and $2.65 \mathrm{~m}$ above N.A.P. (Dutch Ordnance Level, corresponding approximately with mean sea level). The LM vegetation was dominated by Spartina anglica, Aster tripolium and Salicornia dolichostachya. Puccinellia maritima and Aster tripolium were the dominant species of the MM location. On the CL location Elymus pycnanthus was the single species.
The root material used in this study was collected from monospecific stands of Spartina anglica by taking soil cores from 5 to $30 \mathrm{~cm}$ depth. Roots and rhizomes were separated from soil particles using a $1.0 \mathrm{~mm}$ mesh sieve. Living root material was collected and dried at $60^{\circ} \mathrm{C}$. (Roots and rhizomes were considered to be alive when they were white). The root material was cut up to obtain pieces not larger than $2 \mathrm{~cm}$. Approximately $6.25 \mathrm{~g}$ of the dry material was put into $10 \times 10 \mathrm{~cm}$ nylon bags with $1 \mathrm{~mm}$ mesh. The litterbags were put out in the LM, MM and CL locations on 27 and 28 January $1986 ; 40 \mathrm{~cm}$ cores were carefully extracted from the marsh soil and sliced 30,15 and $3 \mathrm{~cm}$ from the surface level. The cores were replaced in their original position with individual litterbags inserted horizontally at the 30,15 and $3 \mathrm{~cm}$ depth levels (cf. Hackney \& de la Cruz 1980). A 4 th litterbag was placed above-ground on top of each core. These surface litterbags were fastened with pins to prevent them from being washed away during high tides. In each of the 3 locations 37 cores with 4 litterbags were set out in rows, at $50 \mathrm{~cm}$ intervals. On 10 subsequent sampling dates, at each location litterbags of 3 randomly assigned cores were retrieved. The litterbags were returned to the laboratory and growing roots which had penetrated the bags from outside were removed. The contents subsequently were washed carefully in tap water, using a $300 \mu \mathrm{m}$ sieve, dried at $60^{\circ} \mathrm{C}$, weighed and ground.

Chemical analyses were performed on subsamples of the ground litter Ash-free dry weight (AFDW) was determined by combustion of the material for $1 \mathrm{~h}$ at $550^{\circ} \mathrm{C}$ in a muffle furnace. Carbon was determined by gravimetric measurements of absorbed $\mathrm{CO}_{2}$ after combustion with oxygen at $580^{\circ} \mathrm{C}$ in a Coleman $\mathrm{CH}$ Analyzer Model 33. Nitrogen was measured in a Carlo Erba Automatic Nitrogen Analyzer Model 1400. Percentage

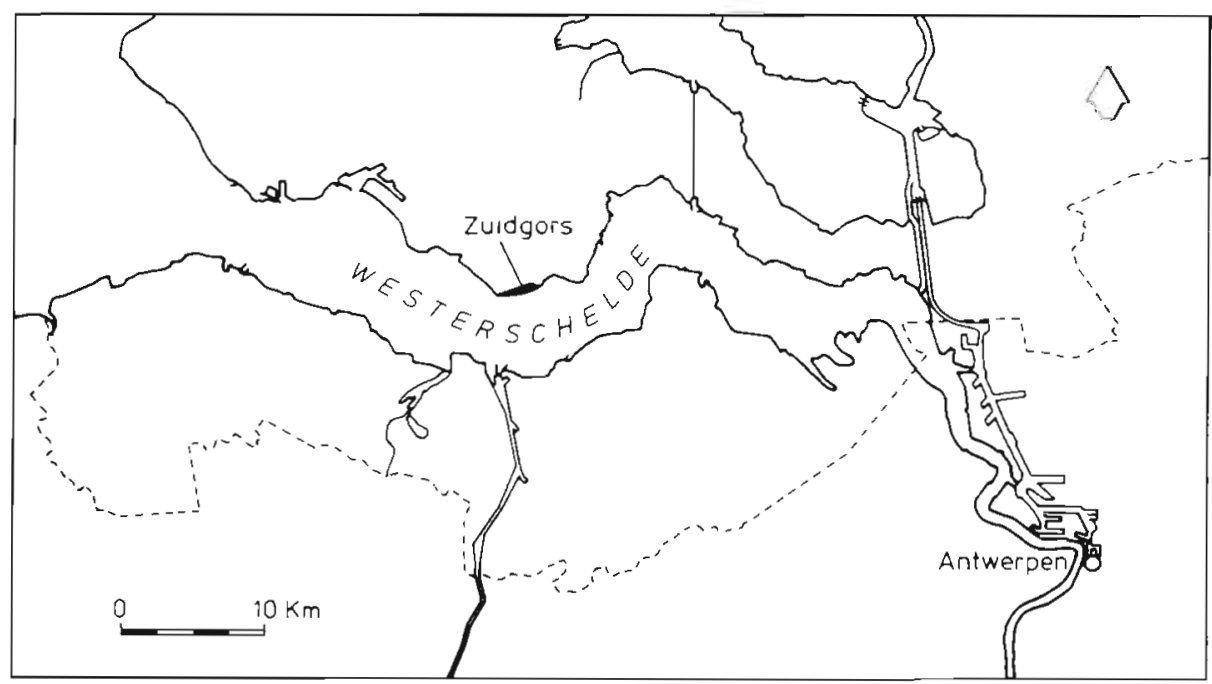

Fig. 1. Study site along Westerschelde estuary in southwest Netherlands 
carbon and nitrogen were calculated on an ash-free dry weight basis, to avoid false values resulting from silt adhering to the litter.

For estimation of protein contents, samples were extracted in $1 \mathrm{M} \mathrm{NaOH}$ at $100^{\circ} \mathrm{C}$ for $1 \mathrm{~h}$. The solubilized protein was measured colorimetrically with Coomassie Bleu as described by Read \& Northcote (1981). The important advantage of the assay is the lack of interference by other chemicals. It is thus applicable to the measurement of protein concentration of crude plant tissue homogenates (Chiapelli et al. 1979).

Analyses of variance were used for statistical treatment of the data. Arcsin transformation of data to radians was necessary if the distribution of a set of percentages was not normal. As the set of weight loss data included percentages above 100, these data were divided by 1000 for conversion to proportions in the transformation procedure.

Significant differences were determined, using the transformed data, by the Least Significant Difference procedure. Above-ground litterbags of the MM site unfortunately were lost early in the experimental period; therefore the analyses of variance were carried out with the data of the below-ground litterbags only. Covariance analysis was carried out on the linear regressions computed on the data relating nitrogen content to litter weight loss.

\section{RESULTS}

\section{Decomposition rates}

The time course of the percentage AFDW remaining at the 3 locations is illustrated in Fig. 2.

The overall picture on the 3 locations is that of a rather gradual decline in remaining AFDW during the entire course of the experimental period (408 d). Despite low temperatures in the first months of the experiment (winter), a decrease in ash-free dry weights can be observed in spring, without consistent differences between depth levels. During summer differences appear in the CL and LM locations, which persist in the remainder of the experimental period: the root material buried at 15 and $30 \mathrm{~cm}$ depth clearly decomposes slower than the above-ground and superficially buried $(3 \mathrm{~cm})$ material. In contrast to the CL and LM sites, decomposition rates at various depths at the MM location apparently are less different; at the end of the experimental period the percentage remaining AFDW is nearly the same for all 3 depth levels.

Three-way analysis of variance on the below-ground litterbag series (Table 1a, Fig. 3) shows that the depth differences between the $-30,-15$ and $-3 \mathrm{~cm}$ series of the LM and CL sites are significant, decomposition
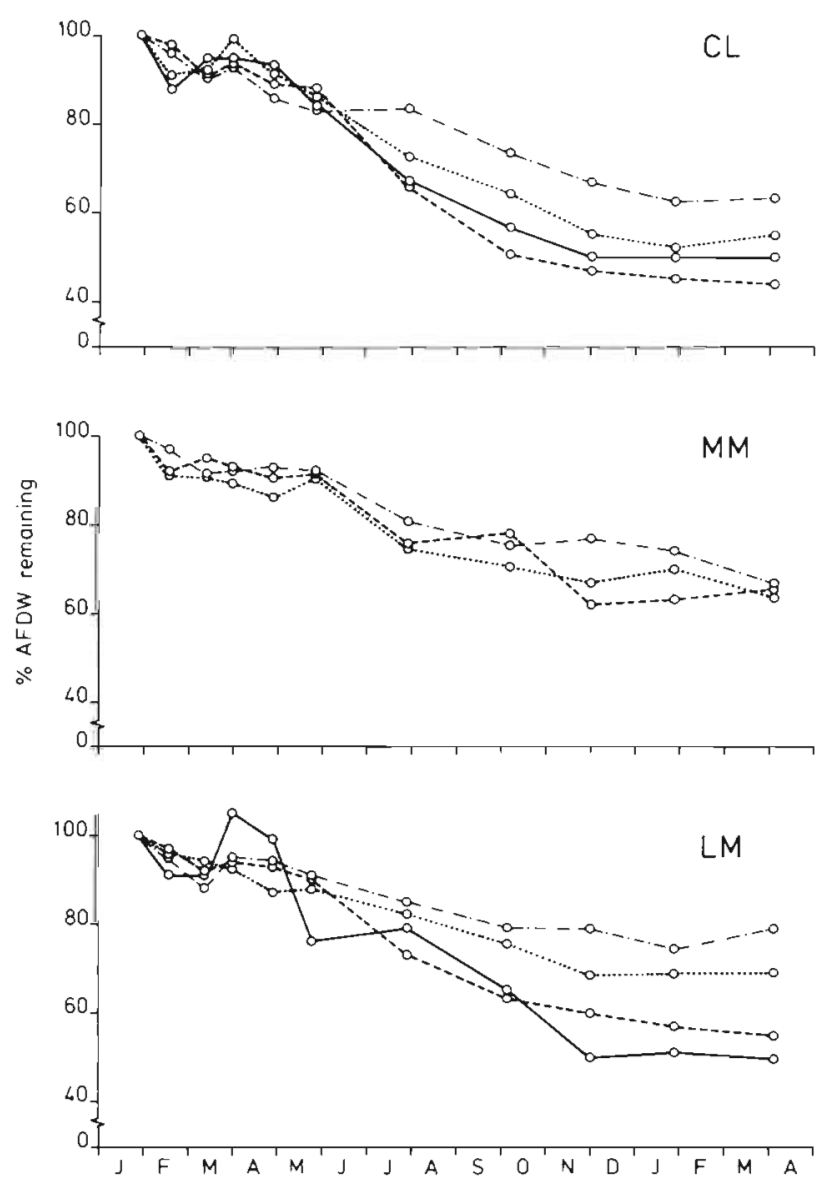

Fig. 2. Percent of ash-free dry weight remaining in litterbags incubated in 3 different habitats at 4 depth levels. Each point represents the average of 3 replicates. CL: creek levee; MM: middle marsh; LM: low marsh. —_: above-ground; -...$-3 \mathrm{~cm} ; \cdots \cdot-15 \mathrm{~cm} ; \cdot-\cdot-:-30 \mathrm{~cm}$

being slower at increasing depths. At the MM site the overall values of the $-30 \mathrm{~cm}$ series are significantly higher than the -15 and $-3 \mathrm{~cm}$ series. Location also has a significant effect; except for the $-3 \mathrm{~cm}$ series of the MM site, the results clearly indicate a higher decomposition rate with increasing elevation of the site (Fig. 3), and therefore with decreasing inundation frequency. In addition, the analysis of variance shows a significant effect of time and a significant interaction of time and depth. These effects can be related to decomposition rates which vary in time and depend on depth level, as is shown by reworking the data of Fig. 2. Decomposition rates per sampling interval were calculated, expressed as percent weight loss per day. Similar depth series of the 3 experimental locations were pooled (Fig. 4). The decomposition rates show a comparable time course pattern above-ground and on the below-ground depth levels: a high initial rate during the first weeks of the experiment is followed by a short phase with negative rates, indicating gain of litterbag contents. Subsequently, there is an extended period of 
Table 1 Analysis of variance of (a) root litter ash-free dry weights; (b) root litter nitrogen levels; (c) root litter protein levels. Analyses were carried out on below-ground data, after arcsin transformation. ${ }^{\circ} p<0.05 ;{ }^{\cdots} p<0.01 ; \cdots p<0.001$

\begin{tabular}{|c|c|c|c|c|c|}
\hline Variable & SS & $\mathrm{df}$ & var & F & $p$ \\
\hline \multicolumn{6}{|l|}{ (a) } \\
\hline Location (1) & $3.48 \times 10^{-2}$ & 2 & $1.74 \times 10^{-2}$ & 58.11 & $\cdots$ \\
\hline Depth (d) & $3.67 \times 10^{-2}$ & 2 & $1.84 \times 10^{-2}$ & 61.34 & $\cdots$ \\
\hline Time $(t)$ & 0.65 & 9 & $7.23 \times 10^{-2}$ & 241.52 & $\cdots$ \\
\hline $1 \times d$ & $7.43 \times 10^{-3}$ & 4 & $1.86 \times 10^{-3}$ & 6.21 & $\cdots$ \\
\hline $1 \times t$ & $4.02 \times 10^{-2}$ & 18 & $2.23 \times 10^{3}$ & 7.45 & $\cdots$ \\
\hline$d \times t$ & 0.045 & 18 & $2.52 \times 10^{-3}$ & 8.43 & $\cdots$ \\
\hline $1 \times d \times t$ & $2.04 \times 10^{-2}$ & 36 & $5.68 \times 10^{-4}$ & 1.90 & $\ldots$ \\
\hline Exp. error & $5.39 \times 10^{-2}$ & 180 & $2.99 \times 10^{-4}$ & & \\
\hline \multicolumn{6}{|l|}{ (b) } \\
\hline Location (1) & $8.19 \times 10^{-3}$ & 2 & $4.10 \times 10^{-3}$ & 18.48 & $\cdots$ \\
\hline Depth (d) & $2.36 \times 10^{-2}$ & 2 & $1.18 \times 10^{-2}$ & 53.30 & $\cdots$ \\
\hline Time $(\mathrm{t})$ & 0.11 & 9 & $1.18 \times 10^{-2}$ & 53.21 & $\cdots$ \\
\hline $1 \times d$ & $9.24 \times 10^{-4}$ & 4 & $2.31 \times 10^{-4}$ & 1.04 & n.s. \\
\hline$I \times t$ & $1.76 \times 10^{-2}$ & 18 & $9.80 \times 10^{-4}$ & 4.42 & $\cdots$ \\
\hline$d \times t$ & $1.74 \times 10^{-2}$ & 18 & $9.65 \times 10^{-4}$ & 4.36 & $\cdots$ \\
\hline $1 \times d \times t$ & $7.39 \times 10^{-3}$ & 36 & $2.05 \times 10^{4}$ & 0.93 & n.s. \\
\hline Exp error & $3.99 \times 10^{-2}$ & 180 & $2.22 \times 10^{-4}$ & - & - \\
\hline \multicolumn{6}{|l|}{ (c) } \\
\hline Location (1) & $2.38 \times 10^{-3}$ & 2 & $1.19 \times 10^{-3}$ & 4.35 & • \\
\hline Depth (d) & $5.89 \times 10^{-4}$ & 2 & $2.94 \times 10^{-4}$ & 1.08 & n.s. \\
\hline Time (t) & 0.16 & 9 & $1.81 \times 10^{-2}$ & 66.22 & $\cdots$ \\
\hline $1 \times d$ & $1.36 \times 10^{-3}$ & 4 & $3.41 \times 10^{-4}$ & 1.25 & n.s. \\
\hline $1 \times t$ & $5.73 \times 10^{-3}$ & 18 & $3.18 \times 10^{-4}$ & 1.16 & n.s. \\
\hline$d \times t$ & $2.24 \times 10^{-3}$ & 18 & $1.25 \times 10^{-4}$ & 0.46 & n.s. \\
\hline Exp. error & & 36 & $2.74 \times 10^{-4}$ & & \\
\hline
\end{tabular}

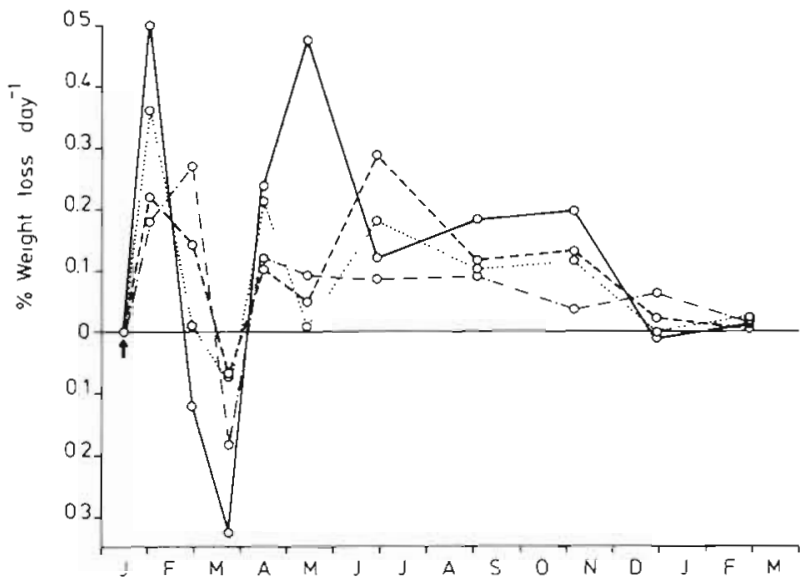

Fig. 3. Interaction between marsh location and depth level at which litterbags were buried. Elevation of marsh locations (cm above Dutch Ordnance Level.) given between brackets. Lettering and lines as in Fig. 2

more or less gradual weight loss. Decomposition rates decrease to very low values in the last phase of the experimental period during wintertime. Although the general pattern is the same on all 4 levels, the rates attain their peak values (both positive and negative) in the above-ground series. During the main decomposition phase from spring to autumn, rate fluctuations are less pronounced with increasing depth. Furthermore,

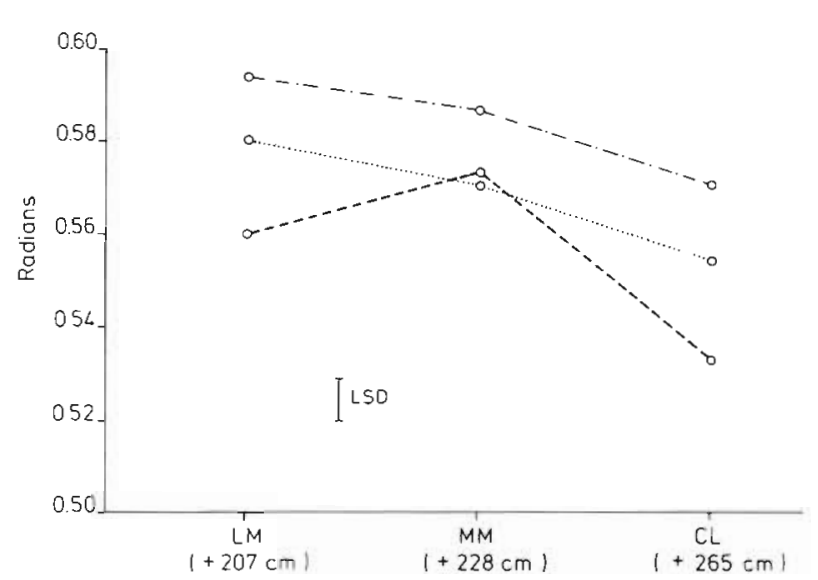

Fig. 4. Rates of litter weight loss at the 4 depth levels, calculated per sampling interval. For calculations, data of similar depth series of the 3 marsh locations were pooled. Lines as in Fig. 2

weight losses are lower with increasing depth during this period.

\section{Nitrogen levels}

Percentage nitrogen in the litter clearly increases in the course of the decay process (Fig. 5). Although an 

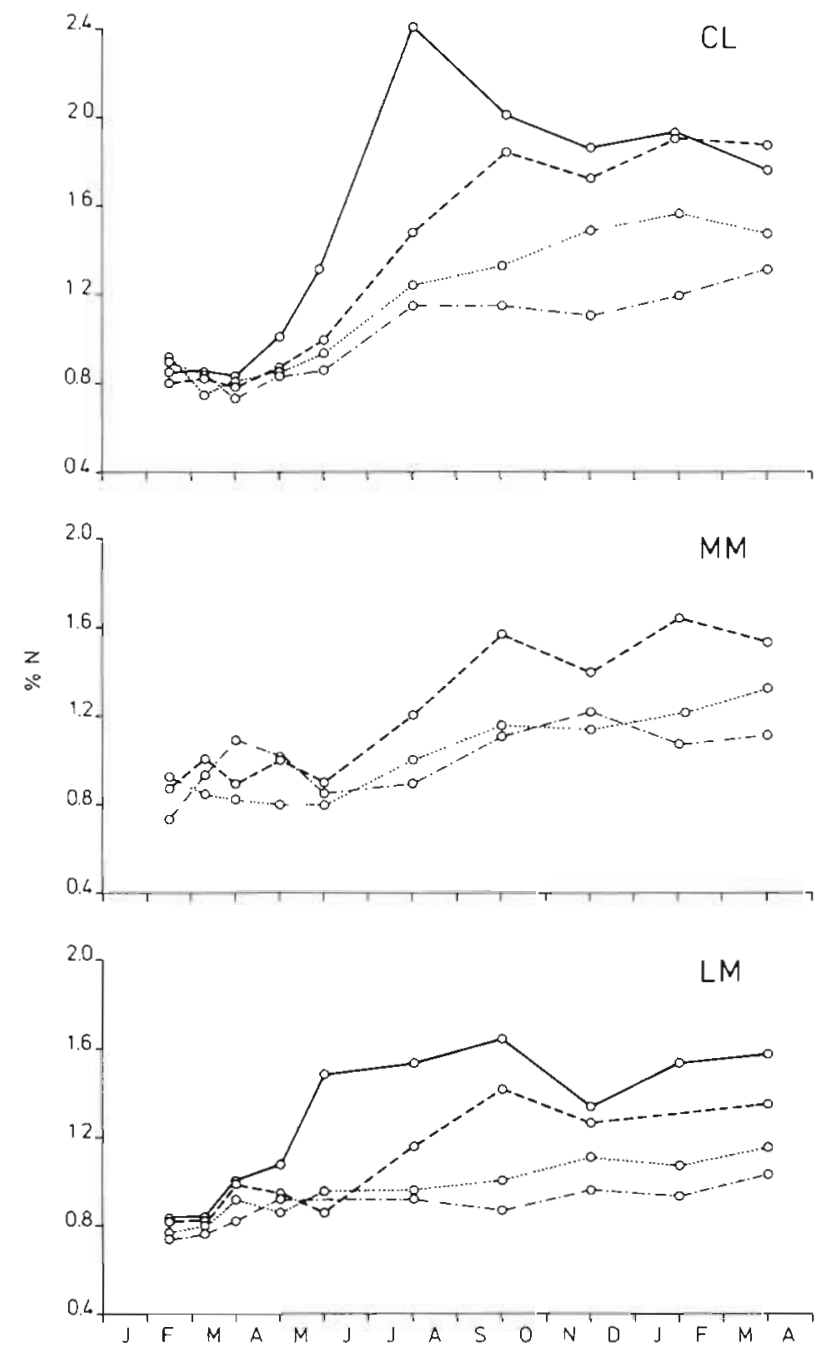

Fjg. 5. Percentage nitrogen in root litter (AFDW) during decomposition. Each point represents the average of 3 replicates. Lettering and lines as in Fig. 2

increase is found at all 3 sites, both above-ground and below-ground, there is nonetheless a highly significant effect of location and of depth (Table $1 \mathrm{~b}$ ). The increase in percentage nitrogen is particularly conspicuous on the CL site, where decomposition of the litter in terms of weight loss (Fig. 2) is most prominent. With increasing depth the gains in nitrogen levels are lower, a finding which runs parallel with the decreasing decomposition at increasing depth level. Further analysis demonstrates that there is a highly significant regression $(p<0.001)$ between the nitrogen percentage and the percentage weight loss on each depth level (Fig. 6). Analysis of covariance shows that there is no significant difference in slope between the regression lines ( $p$ $=0.143$ ), indicating that the rate of nitrogen increase depends similarly on progressive weight loss at all 4 depth levels.

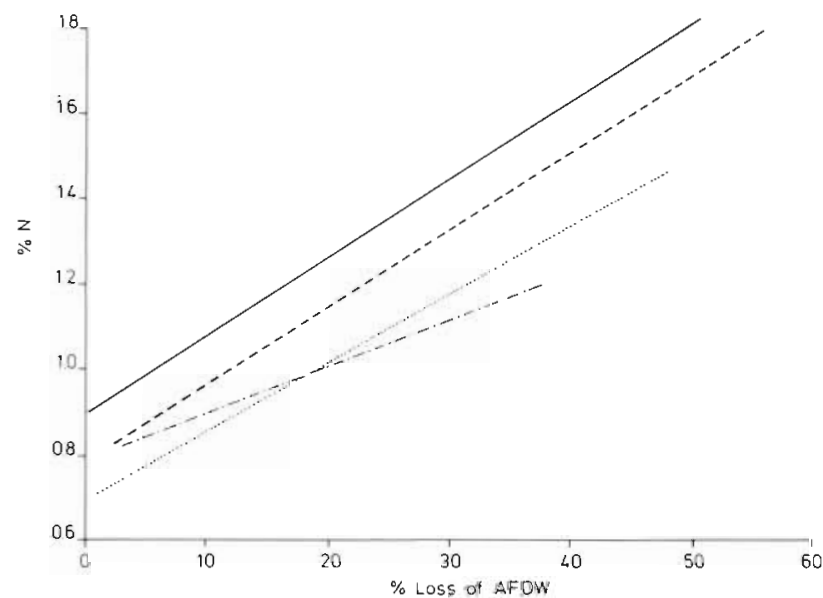

Fig. 6. Regression between percentage nitrogen in root litter and percentage weight loss at the 4 investigated depth levels. Lines as in Fig. 2

\section{Protein levels}

In remarkable contrast to the percentage nitrogen, the percentage protein in the litter decreases rapidly to undetectable levels already a few months after the start of the experimental period (Fig. 7). Analysis of variance (Table 1c) shows that the effect of location is significant, but only at the 0.05 level; no significant effect of depth was found.

\section{DISCUSSION}

\section{Decomposition rates}

Surface decomposition studies of above-ground plant material generally have shown that the pattern of decay can be divided into 3 phases with different processes dominating each phase. An initial phase characterized by rapid weight loss of the litter, due to the physical process of leaching of soluble compounds, is followed by an extended period of active microbial decomposition. Remaining refractory compounds are degraded only very slowly in a final third stage (Swift et al. 1979). These phases have also been observed for litter of salt marsh plants (Frasco \& Good 1982, McKee \& Seneca 1982, Buth \& de Wolf 1985, Valiela et al. 1985). The few studies available on below-ground decomposition in salt marshes give variable results in this respect. A leaching phase can be distinguished in the results of Van der Valk \& Attiwill (1983) and of Valiela et al. (1984). In contrast, Hackney \& de la Cruz (1980) and Buth (1987) did not find distinctive phases. In the present study, above-ground and below-ground decomposition of Spartina anglica root material proceeds rather gradually in time (Fig. 2); however, when 

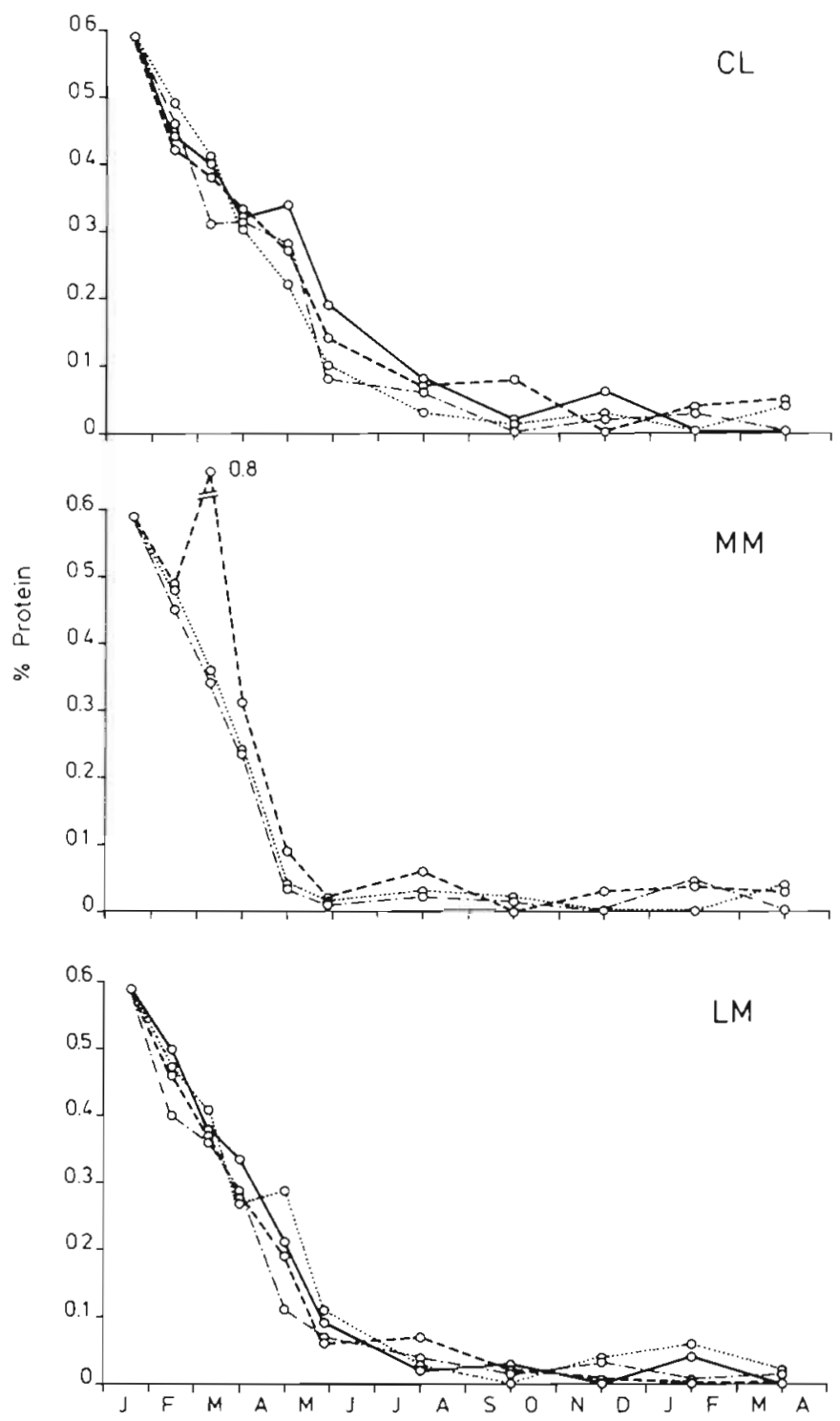

Fig. 7 Percentage extractable protein in root litter during decomposition. Each point represents the average of 3 replicates. Lettering and lines as in Fig. 2

decay rates per sampling interval are calculated, severai phases can be distinguished. The high initial rates strongly suggest that leaching does occur both aboveground and below-ground in a first phase. The fact that leaching apparently is of relatively minor importance in weight loss of Spartina root material, as compared to decay of aerial tissues (Buth \& de Wolf 1985), may be due to a larger proportion of non-leachable material in root tissue. After the high initial weight loss rates, there is a short period in which a process leading to negative weight loss rates (increase of litterbag contents) dominates. The phenomenon of weight gain after initiation of litterbag experiments has also been observed in other studies, and has been explained by the growth of the microbial community on the litter (e.g. Buth 1987 ) or to the association of iron-pyrite with organic matter in the salt marsh soil (Hackney \& de la Cruz 1980. Hackney 1987). Growth of micro-organisms probably is not the cause of the weight increase shown by the present results, as no simultaneous increase in protein is found. Also the association of iron-pyrite with organic matter cannot explain the present findings, as the data apply to ash free dry weights. However, association of carbonates with the root material may be involved. It is known that at higher $\mathrm{pH}$ values $(7$ to 8 ) carbonates in saline soils may precipitate (Goldhaber $\&$ Kaplan 1975). Correction of the remaining root material (dried at $60^{\circ} \mathrm{C}$ ) in the present experiments for ash weight was carried out by combustion of samples at $550^{\circ} \mathrm{C}$. At this temperature, carbon dioxide may form from the precipitated carbonates, resulting in an underestimation of the inorganic part of the litter. This underestimation may result in apparent weight increases after the first phase of weight loss, as the leaching process diminishes in importance, and before the processes leading to gradual weight losses from spring onwards become dominating.

The weight loss which continues through spring, summer and autumn, is found again both aboveground and below-ground. This phase probably is characterized by active microbial decomposition Towards the end of the experimental period, there is a sudden decrease in decay rates. Although the relative proportion of refractory compounds will increase with time, this probably mainly will be due to the drop in temperatures as winter approaches. A true 'refractory phase' (Valiela et al. 1985) may not have been reached during the time span of the experiment. The main point to stress here is the consistency of the observed pattern of decay rates; the course of the decomposition process on the salt marsh is essentially the same above-ground and below-ground: a short early phase dominated by a physical leaching process is followed by an equally short phase with negative weight loss rates possibly as a result of chemical precipitations and, subsequently, an extended phase during which decomposition due to biotic activity gradually proceeds

Of course, the various processes mentioned occur to some extent simultaneously. They are, however, not equally important during each phase

Notwithstanding the similarities mentioned above, the differences in decomposition rates between the various depth levels are conspicuous. The present results show that on the CL and LM sites decomposition rates decrease with increasing depth. This is particularly clear on the LM site, where at the end of the experimental period in the above-ground litterbags only $49 \%$ of the organic material remains, while this is $79 \%$ for the material buried at $30 \mathrm{~cm}$ depth. It is also 
obvious at the CL site, although decomposition at $-3 \mathrm{~cm}$ appears to proceed more quickly than decomposition above-ground. A clear depth effect was also found by Hackney \& de la Cruz (1980): decomposition rate was greatest in the top $10 \mathrm{~cm}$, but no detectable decomposition was found below $20 \mathrm{~cm}$.

There is one aspect of the salt marsh soil which is particularly variable with respect to depth, i.e. oxygen content. Armstrong et al. (1985), in a study of a West European salt marsh, have shown that the oxygen depth profile of the marsh soil is complex and highly variable, coupled to tidal cycles and rainfall. In general, however, the oxygen content of the soil decreases with depth: large-scale alterations of the aeration profile were not found (cf. Howes et al. 1981). The aeration status of the soil may affect aspects of the decomposition process. It is known for instance that the lack of molecular oxygen may hamper the decomposition of some plant materials (lignins, aromatic hydrocarbons; Fenchel \& Blackburn 1979). The aeration status of the soil, however, is not a priori the decisive factor for decomposition rates. Lack of oxygen as such does not inhibit microbial activity or decomposition of most compounds (Howarth \& Hobbie 1982). A recent investigation showed that different degrees of reduction in a North-American salt marsh had no significant effect on below-ground decomposition (Hackney 1987). In agreement with the latter author we think that the presence of living roots is also a significant factor in the decay of organic matter in salt marsh soils. The profile of living below-ground biomass in salt marsh soils generally shows that the bulk of the material is present in the upper soil layers and decreases with depth (e.g. Broome et al. 1975, de la Cruz \& Hackney 1977 Gallagher \& Plumley 1979, Smith et al. 1979, Livingstone \& Patriquin 1981), although exceptions do occur (Groenendijk \& Vink-Lievaart 1987). The present results show that the depth effect is least clear in the MM area, where the vegetation cover was low (ca $40 \%$ ), in contrast to both other study sites. The presence of roots probably is highly important in stimulating soil bacteria activity, as excretion of organic carbon by plant roots in a vegetated soil allows active growth of the microbial population (Lynch 1976). Without the presence of easily available organic carbon exuded by plant roots, bacteria may be severely energy-limited, and mineralization processes in the soil are hampered (Clarholm 1985). In a vegetated soil, the growing roots, next to providing carbon for microbial biomass, render an additional fraction of detrital soil-carbon available to microbial utilization (Helal \& Sauerbeck 1986). Moreover, it is known that sediments under wetland plant species, e.g. Spartina alterniflora, may be more oxidized than unvegetated soils (Armstrong 1975, Howes et al. 1981), a phenomenon probably related to oxygen diffusion from the roots. The more oxic conditions, and the presence of an actively growing microbial population, also are a favourable environment for meiofaunal grazers. In salt marsh soils the meiofauna is dominated by nematodes (Armonies 1986). The potential role of nematodes in stimulating decomposition is most clearly shown by the work of Abrams \& Mitchell (1980). For salt marsh decomposition processes the significance of these animals was suggested by their presence in high numbers in surface litter (Buth \& de Wolf 1985). The mechanical activity of the meiofauna (and macrofauna) in the rooting zone will also help to prevent the local build-up of toxic concentrations of compounds released during the decomposition process. In conclusion, for several reasons the depth effect as found in the present investigation may be significantly related to variable interactions of the living roots with the decomposer community within salt marsh sediments.

An interesting result of the present investigation is the increase in below-ground decomposition with increased elevation of the marsh location (Fig. 4), indicating that the inundation frequency is an important factor in determining the rate of below-ground decay processes. This is understandable as it will influence a number of soil conditions, including soil wetness, aeration status (Armstrong et al. 1985), mean temperature (cf. Buth 1987) and fluctuations in soil salinity (Beeftink 1976); each of these are expected to affect the activity of the soil biota. Apparently, an increasing inundation frequency in this marsh results in a set of environmental conditions which are less favourable for belowground decomposition. With respect to decomposition above-ground, the relation between elevation level and decomposition is less direct (Reice \& Stiven 1983. Buth \& de Wolf 1985, Valiela et al. 1985, this study). A complex of other factors, e.g. transport of particles from the litter by tidal flushing, and surface desiccation during dry months, determine the rates of litter loss here.

By using the values on litter weight remaining 1 yr after start of the experiment, a rough indication of the turnover time of root material in the salt marsh soil can be obtained (Table 2). Turnover times vary, depending on depth and location, between 1.8 and $3.9 \mathrm{yr}$. Although the values pertaining to above-ground decomposition are clearly on the lower end of the range, they are nonetheless of the same order of magnitude. Obviously, below-ground conditions for decomposition in the salt marsh are less favourable only to a limited degree. Considerably higher above-ground decomposition rates have been reported (e.g. Buth \& de Wolf 1985). However, these studies used above-ground plant material, while in the present study root material was used for determination of both above- and below- 
Table 2. Spartina anglica. Decomposition of root material at different depth levels. Values based on weight loss between Jan 1986 and Jan 1987

\begin{tabular}{|c|c|c|}
\hline & $\begin{array}{l}\% \text { weight } \\
\text { loss } \mathrm{yr}^{-1}\end{array}$ & $\begin{array}{l}\text { Turnover } \\
\text { time (yr) }\end{array}$ \\
\hline \multicolumn{3}{|l|}{ CL } \\
\hline Above-ground & 50.0 & 2.0 \\
\hline Below-ground $-3 \mathrm{~cm}$ & 55.0 & 1.8 \\
\hline$-15 \mathrm{~cm}$ & 47.8 & 2.1 \\
\hline$-30 \mathrm{~cm}$ & 37.6 & 2.7 \\
\hline \multicolumn{3}{|l|}{ MM } \\
\hline Above-ground & - & - \\
\hline Below-ground - $3 \mathrm{~cm}$ & 36.7 & 2.7 \\
\hline$-15 \mathrm{~cm}$ & 30.2 & 3.3 \\
\hline$-30 \mathrm{~cm}$ & 26.2 & 3.8 \\
\hline \multicolumn{3}{|l|}{ LM } \\
\hline Above-ground & 49.1 & 2.0 \\
\hline Below-ground - $3 \mathrm{~cm}$ & 43.2 & 2.3 \\
\hline$-15 \mathrm{~cm}$ & 31.0 & 3.2 \\
\hline$-30 \mathrm{~cm}$ & 25.6 & 3.9 \\
\hline
\end{tabular}

ground decomposition rates. Root material can be of a more refractory nature than aerial tissues; aboveground material of Spartina anglica for instance consists of $10 \%$ lignin, root material of ca $30 \%$ lignin (Buth 1987). Below-ground turnover times accord with the estimate of $S$. anglica roots turnover rate obtained in a nearby salt marsh, calculated by dividing maximum standing below-ground crop by the net belowground primary production (Groenendijk \& VinkLievaart 1987). These authors also found that turnover rates of root biomass did not differ much between $S$. anglica and 2 other dominant halophytes of these marshes, Elymus pycnanthus and Halimione portulacoides (turnover times of about $2 \mathrm{yr}$ ). Tumover time of Triglochin maritima roots was calculated to be 4.5 yr. Starting then from a turnover time of root material of 2 to $4 \mathrm{yr}$ in marsh soil, and assuming that transport of detritus particles below-ground is marginal, it is obvious that the amount of decomposing root material in the soil should clearly exceed the living root biomass. In fact, such a pattern has been. found in a salt marsh along the nearby coast of S. E. England, where conditions for below-ground decomposition probably are comparable (Hussey \& Long 1982). However, accumulation of organic matter in the soil complex of the Zuidgors marsh and other estuarine marshes in S. W. Netherlands is limited (cf. Beeftink et al. 1977, Groenendijk \& Vink-Lievaart 1987). The solution to this apparent contradiction probably lies in the local accretion rates of these marshes. Tidal salt marsh deposits showing high accretion rates usually have relatively low organic matter contents (Verhoeven et al. 1957). A high accretion rate is in accordance with data of Buth (1987) who determined the weight of living and dead roots in an Eastern Scheldt salt marsh soil. in the upper $15 \mathrm{~cm}$ root material consisted mainly of living biomass, while at 15 to $30 \mathrm{~cm}$ depth mainly decaying roots were found. Accretion at this salt marsh may be more than $1 \mathrm{~cm} \mathrm{Yr}^{-1}$ (Buth unpubl.). Occasional observations of recent artifacts in the sediments of the Westerschelde salt marsh soils also indicate that, locally, accretion rates of 1 to several $\mathrm{cm} \mathrm{yr}^{-1}$ have occurred in the recent past. At these rates, accretion will be a major factor in determining the mineral character of a salt marsh soil. Further measurements are needed on this point.

\section{Chemical changes}

An increase in nitrogen levels with progressive decay has been reported in several studies of aboveground decomposition of salt marsh plant tissues. For below-ground decomposition both an increase (Valiela et al. 1984) and the absence of a discernible change (Hackney \& de la Cruz 1980) have been found. The absence of a change found by the last mentioned authors may have been related to the limited decay found during the period of observation. The present results show that increasing nitrogen percentages are strongly correlated with progressive decay. There is an interesting contrast between the increasing nitrogen and decreasing protein levels during the course of the experimental period. These results clearly indicate that the increase in nitrogen cannot be attributed to increases in microbial protein due to growth of decomposer micro-organism populations. More likely, nitrogen increase is the result of condensation of reactive phenolics and other compounds, released during decomposition, with microbial exudates; during the decay process, the litter becomes increasingly enriched by these nitrogen containing, but decay resistant complexes (Rice 1982, MeLillo et al, 1984, Rice \& Hanson 1984, Wilson et al 1986a, b); the similar increase rates of nitrogen relative to weight loss at all depth levels, suggest that there are no qualitative differences in these nitrogen increasing processes at different depths.

The decrease in percentage protein obviously is much faster than the overall decrease in litter weight, and shows that plant tissue proteins are relatively easily lost from the litter as compared to other plant compounds. The decrease may be in part the result of the loss of water soluble proteins by an extended leaching process; however, as proteins are nitrogen rich and relatively non-resistant to microbial attack, the decline in protein will also be a reflection of decomposer activ- 
ity, resulting in the transformation of the plant tissue proteins. The rapid decline in proteins of roots and rhizomes illustrates that the chemical composition of the litter at least in some respects rapidly changes during the first months of the decay process. In terms of resource quality for the decomposer community, the diminishing protein content must be considered a decline. Interestingly, the time course of the percentage protein is not significantly influenced by depth, and the effect of location is only significant at the 0.05 level. These variables had a highly significant effect on the decline in AFDW. Apparently, decrease in litter protein is much less responsive to environmental factors than most other plant materials. This may be related to the quality of protein as a substrate for microbial metabolism in comparison to the compounds which make up the major part of plant tissue weight, e.g. cellulose, and which are more nutrient-poor. Break-down of these compounds may be dependent for instance on the nutrient status of the soil, while as has been mentioned before, some of these compounds are only decomposed in oxic conditions (cf. Hill et al. 1985) The effect of location within the salt marsh as has been found in studies of above-ground litter decay, and of location and depth, as has been determined in the present study, may therefore only relate to substrates of limited nutritive value.

Acknowledgements. The authors are indebted to Drs C. H. R. Heip, G. van der Velde and A. H. L. Huiskes for critical remarks and to Dr A. G. Vlasblom for advice on statistical analysis.

\section{LITERATURE CITED}

Abrams, B. I. Mitchell, M. J. (1980). Role of nematode-bacterial interactions in heterotrophic systems with emphasis on sewage sludge decomposition. Oikos 35: 404-440

Armonies, W. (1986). Free-living plathelminthes in sheepgrazed and ungrazed supralittoral salt marshes of the North Sea: abundance, biomass, and their significance in food chains. Neth. J. Sea Res. 20: 385-395

Amstrong, W. (1975). Waterlogged soils. In: Etherington, J. R. (ed.) Environment and plant ecology. Wiley, Chichester, p. $181-218$

Armstrong, W., Wright, E. J., Lythe, S., Gaynard, T J. (1985). Plant zonation and the effects of the spring-neap tidal cycle on soil aeration in a Humber salt marsh. J. Ecol. 73: 323-339

Beeftink, W. G. (1976). The coastal salt marshes of Western and Northern Europe: an ecological and phytosociological approach. In: Chapman V. J. (ed.) Wet coastal ecosystems. Elseviers, Amsterdam, p. 109-155

Beeftink, W. G., Daane, M. C., van Liere, J. M. Nieuwenhuize, J. (1977). Analysis of estuarine soil gradients in salt marshes of the Southwestern Netherlands with special reference to the Scheldt estuary. Hydrobiologia 52: 93-106

Broome, S. W., Woodhouse, W. W. Seneca, E. D. (1975). The relationship of mineral mutrients to growth of Spartina alterniflora in North Carolina: II. The effects of N, P, and Fe fertilizers. Soil Sci. Soc. Am. Proc. 39: 301-307

Buth, G. J. C. (1987). Decomposition of roots of three plant communities in a Dutch salt marsh. Aquat. Bot. 29: $123-138$

Buth, G. J. C., de Wolf, L. (1985). Decomposition of Spartina anglica, Elytrigia pungens and Halimione portulacoides in a Dutch salt marsh in association with faunal and habitat influences. Vegetation 62: 337--355

Chiapelli, F., Vasil, A., Haggerty, D. F. (1979). The protein concentration of crude cell and tissue extracts as estimated by the method of dyebinding: comparison with the Lowry method. Analyt. Biochem. 94: 160-165

Clarholm, M. (1985). Interactions of bacteria, protozoa and plants leading to mineralization of soil nitrogen. Soil Biol. Biochem. 17: 181-187

de la Cruz, A. A., Hackney, C. T. (1977). Energy value, elemental composition, and praductivity of belowground biomass of a Juncus tidal marsh. Ecology 58: 1165-1170

Fenchel, T., Blackburn, T. H. (1979). Bacteria and mineral cycling. Academic Press, New York

Frasco, B. A., Good, R. E. (1982). Decomposition dynamics of Spartina alterniflora and Spartina patens in a New Jersey salt marsh. Am. J. Bot. 69: 402-406

Gallagher, J. L., Plumley, F. G. (1979). Underground biomass profiles and productivity in atlantic coastal marshes. Am. J Bot. 66: 156-161

Good, R. E., Good, N. F., Frasco, B. R. (1982). A review of primary production and decomposition: dynamics of the belowground marsh component. In: Kennedy, V S. (ed.) Estuarine comparisons. Academic Press, New York, p. 139-157

Goldhaber, M. B., Kaplan, J. R. (1975). Controls and consequences of sulphate reduction rates in recent marine sediments. Soil Sci. 119 (1): 42-55

Groenendijk, A. M. (1984). Primary production of four dominant salt marsh angiosperms in the SW-Netherlands. Vegetation 57: 143-152

Groenendijk, A. M., Vink-Lievaart, M. A. (1987). Primary production and biomass on a Dutch salt marsh: emphasis on the below-ground component. Vegetation 70: 21-27

Hackney, C. T. (1987). Factors affecting accumulation or loss of macroorganic matter in salt marsh sediments. Ecology 68: 1109-1113

Hackney, C. T., de la Cruz, A. A. (1980). In situ decomposition of roots and rhizomes of two tidal marsh plants. Ecology 61: $226-231$

Helal, H. M., Sauerbeck, D. (1986). Effect of plant roots on carbon metabolism of soil microbial biomass. Z. Pflanzenernähr. Bodenk. 149: 181-188

Hill, M. O., Latter, P. M., Bancroft, G. (1985). A standard curve for intersite comparison of cellulose degradation using the cotton strip method. Can. J. Soil Sci. 65: 609-619

Howarth, R. W., Gibbin, A., Gale, J., Peterson, B. J., Luther, G. W (1983). Reduced sulfur compounds in the pore waters of a New England salt marsh. Ecol. Bull. (Stockholm) 35: 135-152

Howarth, R. W., Hobbie, J. E. (1982). The regulation of decomposition and heterotrophic microbial activity in salt marsh soils: a review. In: Kennedy, V S. (ed.) Estuarine comparisons. Academic Press, New York, p. 183-208

Howarth, R. W., Teal, J. M. (1980). Energy flow in a salt marsh ecosystem: the role of reduced inorganic sulfur compounds. Am. Nat. 116: 862-872

Howes, B. L., Howard, R. W., Teal, J. H., Valiela, I. (1981) Oxidation reduction potentials in a salt marsh: spatial 
patterns and interactions with primary production. Limnol. Oceanogr. 26: 350-360

Hussey, A., Long, S. P. (1982). Seasonal changes in weight of above- and below-ground vegetation and dead plant material in a salt marsh at Colne point, Essex. J. Ecol. 70: $757-771$

Livingstone, D. C., Patriquin, D. G. (1981). Belowground growth of Spartina alterniflora Loisel: habits, functional biomass and non-structural carbohydrates. Estuar. coast. Shelf Sci. 12: 579-587

Long, S. P., Mason, C. F. (1983). Salt marsh ecology. Blackie, Glasgow

Lynch, J. M. (1976). Products of soil microorganisms in relation to plant growth. Crit. Rev. Microbiol. 5: 67-107

McKee, K. L., Seneca, E. O. (1982). The influence of morphology in determining the decomposition of two sait marsh macrophytes. Estuaries 5: 302-309

MeLillo, J. M., Naiman, R. J., Aber, J. D., Linkins, A. E. (1984). Factors controlling mass loss and nitrogen dynamics of plant litter decaying in northern streams. Bull. mar. Sci. 35: $341-356$

Read, S. M., Northcote, D. H. (1981). Minimization of variation in the response to different proteins of the Coomassie Bleu $G$ dye-binding assay for protein. Analyt. Biochem. 116: 53-64

Reice, S. R., Stiven, A. E. (1983). Environmental patchiness, litter decomposition and associated faunal patterns in a Spartina alterniflora marsh. Estuar. coast. Shelf Sci. 16: $559-571$

Rice, D. L. (1982). The detritus nitrogen problem: new observations and perspectives from organic geochemistry. Mar Ecol. Prog. Ser. 9: 153-162

Rice, D. L., Hanson, R. B. (1984). A kinetic model for detritus nitrogen: role of associated bacteria in nitrogen accumulation. Bull. mar. Sci. 35: 326-340
Russell, R. S. (1977). Plant root systems: their function and interaction with the soil. McGraw-Hill, London

Smith, K. K., Good, R. E., Good, N. F. (1979). Production dynamics for above and below ground components of a New Jersey Spartina alterniflora tidal marsh. Estuar. coast. mar Sci. 9: 189-201

Swift, M. J., Heal, O. W., Anderson, J. M. (1979). Decomposition in terrestrial ecosystems. Blackwell, Oxford

Valiela, I., Teal, J. M., Allen, S. E., van Etten, R., Goehringer, D., Volkmann, S. (1985). Decomposition in salt marsh ecosystems: the phases and major factors affecting disappearance of above-ground organic matter J. exp. mar Biol. Ecol. 89: 29-54

Valiela, I., Wilson, J., Buchsbaum, R., Rietsma, C., Bryant, D., Foreman, K., Teal, J. (1984). Importance of chemical composition of salt marsh litter on decay rates and teeding by detritivores. Bull. mar. Sci. 35: 261-269

van der Valk, A. G., Attiwill, P. M. (1983). Above- and belowground litter decomposition in an Australian salt marsh Austr. J. Ecol. 8: 441-447

Verhoeven, B., Bakker, D., Kluytenaar, J., Sieben, W. H (1957). Over het in cultuur brengen van de Quarlespolder. Van zee tot land 20: $1-43$

Wilson, J. O., Buchsbaum, R., Valiela, I., Swain, T (1986a). Decomposition in salt marsh ecosystems: phenolic dynamics during decay of litter of Spartina alterniflora. Mar. Ecol. Prog. Ser. 29: 177-187

Wilson, J. O., Valiela, I., Swain, T. (1986b). Carbohydrate dynamics during decay of litter of Spartina alterniflora. Mar Biol. 92: 277-284

Wolff, W J., van Eeden, M. J., Lammens, E. (1979). Primary production and import of particulate organic matter on a salt marsh in the Netherlands. Neth. J. Sea Res. 13: $242-255$

This article was presented by Dr G. W. Thayer; it was accepted for printing on July 19, 1988 